\title{
Pedogenesis Dan Klasifikasi Tanah Yang Berkembang Dari Dua Formasi Geologi Dan Umur Bahan Erupsi Gunung Tangkuban Perahu
}

\section{Mahfud Arifin 1), Rina Devnita1), Ridha Hudaya'), Apong Sandrawati1), Daud S. Saribun1), Rachmat Harryanto ${ }^{1)}$ dan Ganjar Herdiansyah ${ }^{2)}$}

\author{
${ }^{1}$ Staff Pengajar Departemen Ilmu Tanah dan Sumberdaya Lahan, Fakultas Pertanian \\ Universitas Padjadjaran \\ ${ }^{2}$ Alumni Program Magister Ilmu Tanah, Fakultas Pertanian, Universitas Padjadjaran \\ Jl. Raya Bandung Sumedang Km 21 Jatinangor \\ Korespondensi: smahfud_arifins@yahoo.com; apong.sandrawati@unpad.ac.id
}

\begin{abstract}
The efforts to utilize the agricultural land need a proper understanding of the soil characteristics. The soil characteristics themselves are influenced by the factors that regulate and control the soil forming and pedogenesis processes. The main soil forming factors in this study was the different ages and composition of parent materials from the eruption of Mt. Tangkuban Parahu in West Java. This research was done to comprehend the pedogenesis and to figure out the soil classifications that developed in two geological formations (Qyd and Qvu) and two ages of eruption (Holocene and Pleistocene) of Mt. Tangkuban Parahu. The study was conducted in Ciater, Subang Regency and Jatinangor, Sumedang Regency in West Java Province. The study consisted of four stages: preparation, field survey and soil sampling, laboratory analysis and presenting the report. The results showed that Pedon of Jatinangor consisted of three different stratifications of ages. The clay mineralogical composition was dominated by kaolinite, whereas mineralogical composition of the sandy fractions (heavy fractions) was augite-hypersthene. Pedon of Ciater also consists of three different stratifications of age. The clay mineralogical composition was dominated by allophane, while mineralogical compositions of the sandy fractions (heavy fractions) were green amphibolehypersthene in the overlying horizons and amphibole-augite in the underlying horizons. The stage of soil formation on both pedon were cambic or viril. The soil classification according to Soil Taxonomy were Acrudoxic Durudands, medial over loamy-skeletal, isohyperthermic in Ciater Pedon and Fluventic Eutrudepts, fine, kaolinitic, isohyperthermic in Jatinangor Pedon.
\end{abstract}

Key words: slow sand filter, activated carbon, silica sand, sand, gravel, zeolite

\section{PENDAHULUAN}

Tanah merupakan benda alam yang terus-menerus berubah akibat dari proses pelapukan. Proses pelapukan tanah dipengaruhi oleh faktor-faktor pembentukan tanah yaitu bahan induk, iklim, topografi, organisme dan waktu. Faktor pembentuk tanah ini akan saling mempengaruhi dalam menghasilkan sifat dan karakter dari tanah tersebut. Namun, dalam kondisi tertentu salah satu dari faktor pembentuk tanah ini akan lebih dominan dalam menghasilkan sifat-sifat tanah.

Tanah yang dijadikan areal penelitian merupakan lahan Kebun Percobaan Fakultas Pertanian Universitas Padjadjaran yang terletak di Kecamatan Jatinangor, Kabupaten Sumedang dan di wilayah Ciater Kabupaten Subang. Kedua wilayah ini memiliki formasi geologi yang berbeda umur letusan dari sumber gunungapi yang sama.

Berdasarkan hasil pemetaan geologi skala 1:100.000 yang dilakukan oleh Pusat Penelitian dan Pengembangan Geologi tahun 1973, dilaporkan bahwa daerah Jatinangor termasuk ke dalam Formasi Geologi Qyu (Quarter young unidentified) yang berumur plistosin, sedangkan daerah Ciater termasuk ke dalam Formasi Geologi Qyd (Quarter young dano) yang berumur holosin akhir. Qyu merupakan hasil gunung api muda tak teruraikan bersifat andesitik-basaltik 
sedangkan Qyd merupakan tufa pasir. Perbedaan geologi ini akan menyebabkan perbedaan sifat-sifat tanah yang dihasilkan. Hasil pemetaan dari Lembaga Penelitian Tanah (LPT) Bogor pada tahun 1971, menunjukkan bahwa tanah di wilayah Jatinangor diklasifikasikan sebagai Latosol, sedangkan di wilayah Ciater diklasifikasikan sebagai Andosol menurut Sistem Klasifikasi Tanah Dudal-Soepraptohardjo (1961).

Bahan induk merupakan faktor utama yang mempengaruhi proses pembentukan tanah di lokasi penelitian. Tan (1965) mengemukakan bahwa di Indonesia tanah ini berkembang dari bahan induk yang beragam, sehingga perkembangan ataupun sifat-sifat tanah yang terbentuk akan berbeda.

Daerah Jatinangor (760 mdpl) termasuk pada Zona Agroklimat B2 (Oldeman, 1975) dengan jumlah curah hujan tahunan sebesar $2000 \mathrm{~mm}$. Bentuk wilayah umumnya bergelombang sampai agak berbukit. Penggunaan lahan berupa ladang/tegalan dengan vegetasi jagung, kacang tanah, singkong, cabe merah. Ciater terletak di daerah perbukitan/pegunungan dengan ketinggian $1250 \mathrm{~m}$ dpl. Penggunaan lahan berupa perkebunan teh, ladang/tegalan dengan vegetasi tanaman hortikultura.

Penelitian ini dilaksanakan untuk mengungkapkan informasi tentang karakteristik tanah di Jatinangor dan Ciater yang meliputi sifat-sifat morfologi, kimia, fisika, mineral (mineralogi) serta prosesproses pedogenesis yang menyertai pembentukan tanah dan klasifikasi tanahnya berdasarkan Soil Taxonomy (Soil Survey Staff, 2014).

Hasil penelitian ini diharapkan dapat memberikan informasi awal atau data dasar mengenai karakteristik tanah di lokasi kajian sehingga bisa memberikan arahan pengembangan pertanian dan penelitianpenelitian yang akan dilakukan.

\section{METODE PENELITIAN}

Pengamatan morfologi tanah dan keadaan lingkungan serta pengambilan contoh tanah untuk keperluan analisis di laboratorium (fisika, kimia, dan mineralogi) dilakukan pada satu buah pedon di Ciater yang berkembang dari tufa pasir yang berumur holosen akhir, serta satu buah pedon di Jatinangor yang berkembang dari dari hasil gunung berapi tak teruraikan yang berumur plistosen. Letak pedon tersebut ditetapkan berdasarkan hasil pengamatan, sehingga cukup representatif untuk mewakili tanah di areal tersebut.

Analisis laboratorium dilakukan di Laboratorium Kesuburan Tanah dan Nutrisi Tanaman dan Laboratorium Fisika Tanah Departemen Ilmu Tanah Fakultas Pertanian Universitas Padjadjaran di Jatinangor. Analisis mineral dilakukan di Laboratorium Mineralogi Balai Penelitian Tanah di Bogor. Penetapan mineral liat dilakukan dengan analisis diferensial termik (Differential Thermal Analysis/DTA).

Penentuan lokasi penelitian dilakukan melalui survai lapang terlebih dahulu untuk menentukan sub ordo tanah dengan bantuan Peta Tanah Indonesia, LPT (1985) skala 1 : 2.500.000, dan Peta Tanah Jawa Barat (LPT, 1973) skala 1 : 250.000, Peta Rupa Bumi Lembar Subang dan Lembar Jatinangor (Bakosurtanal, 2007) skala $1: 25.000$, serta Peta Geologi Lembar Bandung, Jawa (Pusat Penelitian dan Pengembangan Geologi, 1973) Skala 1 : 100.000. Penetapan taksa tanah didasarkan Taksonomi Tanah (Soil Survey Staff , 1999, 2014) dan Rochim dan Arifin, (2011) melalui pembuatan dan pengamatan pedon tanah di dua areal kajian untuk mendapatkan dua taksa tanah yang secara morfologis berbeda. Dua areal tersebut mempunyai kemiringan lahan, penggunaan lahan, dan curah hujan yang relatif sama dan memiliki bahan induk yang berbeda.

Pengamatan pedon tanah dilakukan dari lubang yang berukuran $2 \mathrm{~m} \times 1 \mathrm{~m} \times 1,5 \mathrm{~m}$, memanjang ke arah Barat-Timur yang dilengkapi dengan tangga, sehingga memudahkan pengamatan dan memungkinkan cahaya matahari dapat masuk ke dalam lubang profil dengan leluasa. Dekripsi profil 
tanah berpedoman pada buku panduan "Soil Survey Staff, 1999“. Pengamatan morfologi tanah meliputi penetapan horison, warna (matrik dan karatan), tekstur, struktur, konsistensi, bahan organik, pori-pori, padas dan lainnya. Setiap horison diamati dan dicatat sifat morfologinya kemudian diambil contohnya untuk keperluan klasifikasi tanah sampai tingkat famili.

\section{HASIL DAN PEMBAHASAN}

\subsection{Morfologi Tanah}

Hasil pengamatan di Pedon Jatinangor terhadap sifat morfologi tanahnya menunjukkan adanya 11 horison tanah, yang dapat dikelompokan menjadi 3 sekum/timbunan bahan yang berbeda (lithologic discontinuity), yaitu timbunan pertama sampai kedalaman $50 \mathrm{~cm}$ dari permukaan tanah yang terdiri dari empat horison (Ap, AB, Bw1, Bw2); timbunan kedua dari kedalaman $50 \mathrm{~cm}$ sampai dengan $138 \mathrm{~cm}$ yang terdiri dari empat horison (2A'b, 2B'w1, 2B'w2, 2Bw3) dan timbunan ketiga dari kedalaman $138 \mathrm{~cm}$ sampai dengan $200 \mathrm{~cm}$ yang terdiri dari tiga horison (3a"b, 3B"w1, 3B"w2). Perkembangan horison pada setiap sekum merupakan ciri bahwa selang waktu penimbunan volkanik (umur erupsi) cukup lama.

Warna tanah lembab sampai kedalaman $50 \mathrm{~cm}$ dari permukaan tanah berkisar dari coklat gelap (7,5 YR3/4) sampai coklat kemerahan gelap (5YR3/4), sedangkan warna tanah pada kedalaman $50-200 \mathrm{~cm}$ memiliki warna lebih terang yaitu merah kekuningan (5YR 4/6). Terdapat beberapa perbedaan dari segi warna pada timbunan pertama lebih gelap/tua dibandingkan dengan dua timbunan di bawahnya, dan timbunan ke dua dan ke tiga memiliki warna tanah yang hampir sama.

Pedon Ciater menunjukkan sifat morfologi tanahnya yaitu warna tanah berkisar dari coklat tua kemerahan (5YR 3/3) sampai coklat kekuningan (10YR 5/6 - 5/8). Horison permukaan berkisar dari warna coklat tua (10YR 3/3) sampai coklat tua kekuningan (10YR 3/4). Horison A tertimbun umumnya berwarna lebih gelap dari horison di atasnya sedangkan horison B dan BC berwarna lebih terang dari horison di atasnya. Pedon ini menunjukkan adanya stratifikasi bahan volkan yang berbeda akibat penimbunan hasil erupsi volkanik yang berulang-ulang. Horison permukaan (Ap) berwarna gelap akibat akumulasi bahan organik yang tinggi, dalam kaitannya dengan umur dan sifat bahan induk pedon ini tidak memperlihatkan perbedaan warna yang mencolok. Hasil ini diduga sifat bahan induk basaltik pada kondisi curah hujan yang relatif tinggi, telah menyebabkan warna tanah cenderung coklat tua kekuningan.

\subsection{Susunan Mineral Fraksi Pasir}

Hasil analisis mineral fraksi pasir (fraksi IV) pada Pedon Jatinangor memperlihatkan adanya asosiasi mineral fraksi berat yang berbeda berdasarkan susunan horisonnya. Hal ini menunjukkan adanya penimbunan bahan volkanik yang berbeda umurnya walaupun bahan induknya relatif sama yaitu andesitik (plagioklas intermedier). Fenomena seperti ini biasa terjadi pada tanah-tanah yang berkembang dari abu volkan akibat erupsi yang berulang-ulang dalam interval waktu yang berlainan.

Komposisi mineral pada masing-masing horizon dapat dilihat pada Tabel 1. Susunan mineral utama pada fraksi total bahan muda yang paling atas (timbunan terakhir) ialah konkresi dan amfibol hijau, sedangkan pada timbunan kedua ialah konkresi besi dan pada timbunan yang paling bawah ialah bahan hancuran dan konkresi besi. Hasil analisis menunjukkan makin tua bahan volkanik maka makin tinggi kandungan mineral opaknya (magnetit) sedangkan kandungan konkresi besinya makin berkurang. Hal ini memperlihatkan bahwa semakin tua bahan volkanik maka konkresi besi akan berubah menjadi magnetit. Pada timbunan bahan volkanik terakhir (lapisan $50 \mathrm{~cm}$ paling atas) 
kandungan mineral mudah lapuknya ditemukan masih tinggi, hal ini menunjukkan masih tingginya cadangan mineral pada lapisan top soil. kandungan mineral bahan hancuran atau hasil pelapukan mineral- mineral asal pada seluruh horison jumlahnya sangat sedikit sampai tidak ada, kecuali pada lapisan yang paling atas yang kemungkinan besar terkontaminasi oleh erupsi segar dari gunungapi sekitarnya (Gunung Galunggung).

Tabel 1 Komposisi Mineral Fraksi Pasir (Fraksi IV) Pedon Jatinangor

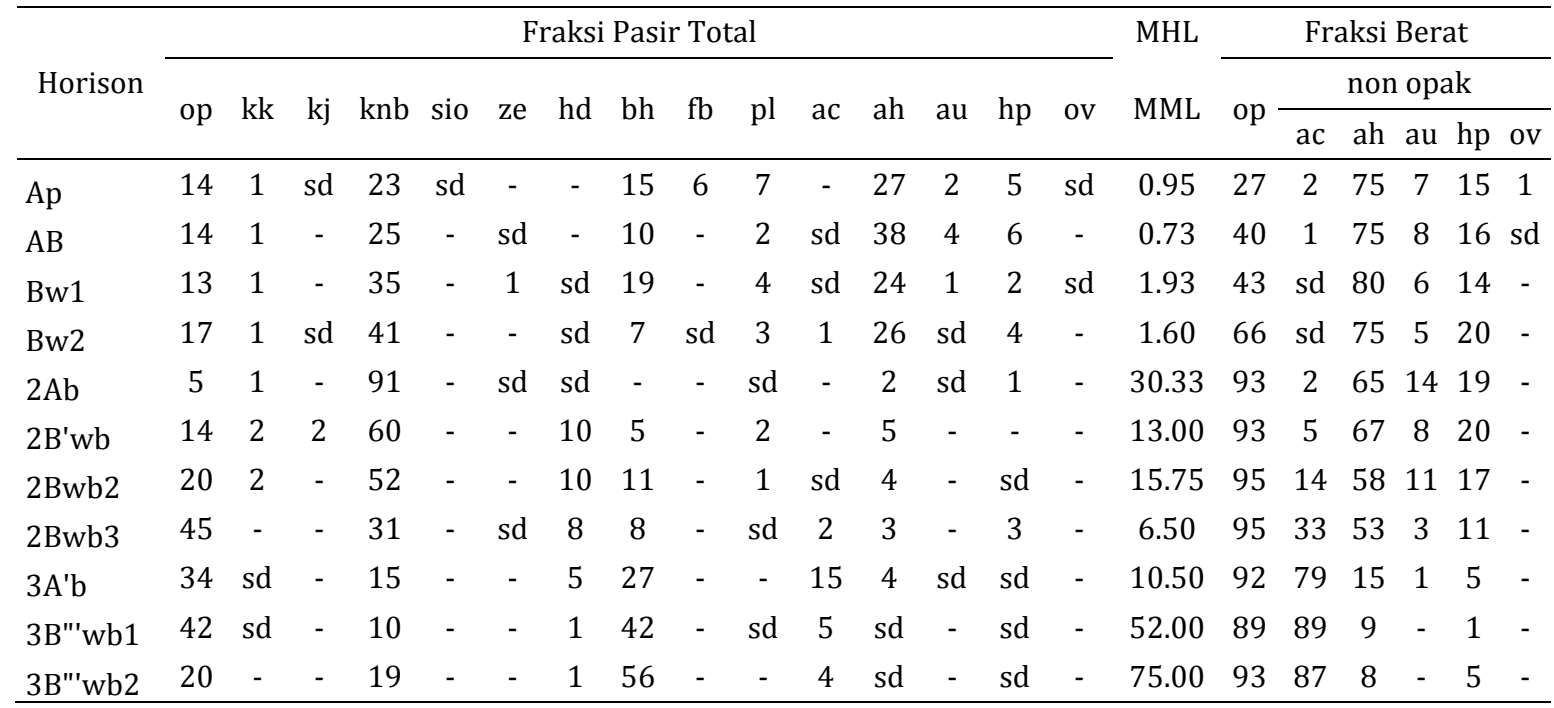

Tabel 2 Komposisi Mineral Fraksi Pasir Pedon Ciater

\begin{tabular}{|c|c|c|c|c|c|c|c|c|c|c|c|c|c|c|c|c|c|c|c|c|c|c|}
\hline \multirow{3}{*}{ Horison } & \multicolumn{15}{|c|}{ Fraksi Pasir Total } & \multirow{3}{*}{$\begin{array}{l}\text { MHL } \\
\text { MML }\end{array}$} & \multicolumn{6}{|c|}{ Fraksi Berat } \\
\hline & \multirow{2}{*}{ op } & \multirow{2}{*}{$\mathrm{kj}$} & \multirow{2}{*}{$\mathrm{knb}$} & \multirow{2}{*}{ sio } & \multirow{2}{*}{ ze } & \multirow{2}{*}{ bh } & \multirow{2}{*}{$\mathrm{fb}$} & \multirow{2}{*}{ gv } & \multirow{2}{*}{ an } & \multirow{2}{*}{$\mathrm{lb}$} & \multirow{2}{*}{ bt } & \multirow{2}{*}{ ga } & \multirow{2}{*}{$\mathrm{au}$} & \multirow{2}{*}{ hp } & \multirow{2}{*}{ ov } & & \multirow{2}{*}{ op } & \multicolumn{5}{|c|}{ Non opak } \\
\hline & & & & & & & & & & & & & & & & & & ac & $\mathrm{ah}$ & $\mathrm{au}$ & $\mathrm{hp}$ & ov \\
\hline Ap & - & - & 2 & 1 & 1 & 1 & 44 & 22 & - & 9 & sd & 1 & 18 & 1 & - & 0.04 & 10 & - & 25 & 51 & 24 & - \\
\hline Bw & sd & - & - & sd & sd & 4 & 31 & 28 & - & 7 & - & 8 & 14 & 8 & - & 0.04 & 2 & - & 22 & 51 & 27 & - \\
\hline $\mathrm{BC}$ & 1 & - & 1 & sd & sd & - & 33 & 8 & - & 19 & - & 5 & 20 & 13 & - & 0.01 & 5 & - & 17 & 55 & 28 & - \\
\hline $2 \mathrm{Ab}$ & 3 & - & - & - & $\mathrm{sd}$ & - & 48 & 10 & - & 4 & - & 5 & 24 & 6 & - & 0 & 9 & - & 17 & 72 & 22 & - \\
\hline $2 \mathrm{Bw}$ & 10 & - & 2 & $\mathrm{sd}$ & $\mathrm{sd}$ & 2 & 34 & 2 & - & 24 & - & 2 & 22 & 2 & - & 0.05 & 36 & - & 6 & 89 & 5 & - \\
\hline $2 \mathrm{BC}$ & 6 & - & 8 & $\mathrm{sd}$ & sd & 2 & 40 & - & - & 32 & - & - & 12 & - & - & 0.12 & 20 & - & 3 & 95 & 2 & - \\
\hline $3 \mathrm{Ab}$ & 2 & - & 1 & - & $\mathrm{sd}$ & 3 & 26 & - & - & 27 & - & 32 & 7 & 2 & - & 0.04 & 4 & 1 & 69 & 23 & 7 & - \\
\hline $3 \mathrm{Bw}$ & 1 & - & 1 & sd & $\mathrm{sd}$ & 2 & 14 & - & - & 35 & - & 33 & 11 & 3 & - & 0.03 & 5 & - & 71 & 25 & 4 & - \\
\hline $3 B C$ & 7 & - & 1 & - & - & 1 & 11 & - & - & 19 & - & 44 & 14 & 3 & - & 0.02 & 11 & - & 71 & 24 & 5 & - \\
\hline
\end{tabular}

Keterangan : op = opak; kk = kuarsa keruh; kj = kuarsa jernih; knb = konkresi besi; ze = zeolit; hd= hidragilit; bh = bahan hancuran; $\mathrm{fb}=$ fragmen batuan; $\mathrm{pl}=$ plagioklas; $\mathrm{ac}=$ amfibol coklat; $\mathrm{ah}=$ amfobol hijau; $\mathrm{au}=$ augit; $\mathrm{hp}=$ hiperstion; ov = olivin; gv = gelas volkanik; an = andesit; $\mathrm{lb}=$ labradorit; $\mathrm{bt}=$ bitownit; $\mathrm{MHL}=$ mineral hasil lapukan (knb, sio, bh); MML = mineral mudah lapuk (ze, gv, fb, an, lb, bt, ah, au, hp, ov).

Hasil analisis Pedon Ciater menunjukkan adanya penimbunan bahan volkan yang berulang-ulang dengan adanya asosiasi mineral yang sama atau berbeda. Pedon Ciater memiliki kandungan fragmen batuan yang cukup banyak, memiliki nilai nisbah mineral hasil lapukan (MHL) dan mineral mudah lapuk (MML) relatif kecil. Pedon Ciater terdiri dari tiga stratifikasi bahan yang berbeda asosiasi mineralnya yaitu augit-hiperstin (0$43 \mathrm{~cm}$ ), augit $(43-94 \mathrm{~cm})$ dan amfibol hijau (94-148 cm). Bahan induk dari Pedon Ciater ini bersifat andesitic, hal ini didasarkan pada pengelompokan sifat bahan induk serta penetapan jenis mineral plagioklas.

Berdasarkan analisis mineral ini menunjukkan bahwa bahan volkanik sebagai bahan induk tanah Jatinangor telah berumur 
tua (awal kuarter atau pleistosen) apabila dibandingkan dengan erupsi resen G. Tangkuban Perahu yang membentuk tanahtanah Andisol di Ciater yang berumur holosen.

\subsection{Susunan Mineral Fraksi Liat}

Hasil analisis mineral fraksi liat berdasarkan thermogram DTA dari empat contoh tanah (horison Ap, Bw1, 2Bw2, 3Bw3) menunjukkan bahwa Pedon Jatinangor didominasi oleh mineral liat kaolinit, yang dicirikan dengan puncak reaksi endotermik pada suhu $530^{\circ} \mathrm{C}$. semakin dalam kedalaman tanah menunjukkan semakin tinggi kandungan mineralnya, kecuali pada horison 2Bw2. Selain mineral kaolinit, ditemukan juga mineral haloisit dicirikan dengan puncak reaksi endotermik pada suhu rendah $\left(70-80^{\circ} \mathrm{C}\right)$ dan puncak reaksi eksotermik pada $925^{\circ} \mathrm{C}$. Mineral ketiga yang dijumpai yaitu mineral gibsit dicirikan dengan puncak reaksi endotermik pada suhu 275$285^{\circ} \mathrm{C}$ (Gambar 1; Tabel 3).

Pedon Ciater hasil analisis mineral liat didominasi oleh mineral-mineral ordo kisaran pendek. Mineral alofan dicirikan dengan puncak reaksi endotermik suhu rendah (80$135^{\circ} \mathrm{C}$ ) dan eksotermik suhu tinggi (880920C) (Tan, 1982; Wada, 1989). Horison permukaan (horison Ap) pada pedon ini menunjukkan adanya mineral kaolinit yang dicirikan dengan puncak reaksi endotermik suhu sedang $\left(520^{\circ} \mathrm{C}\right)$. Terbentuknya mineral kaolinit pada lapisan ini akibat terbentuknya ikatan kompleks Al-humus, sehingga lapisan atas kaya dengan Si (silikasi) dan membentuk kaolinit disorder.

\subsection{Sifat-sifat Kimia Tanah}

Hasil analisis laboratorium menunjukkan bahwa $\mathrm{pH} \mathrm{H}_{2} \mathrm{O}$ tanah Pedon Jatinangor berkisar antara 5,42-5,86 yaitu masam sampai agak masam sedangkan $\mathrm{pH} \mathrm{KCl}$ berkisar antara 4,00-4,63. Naik turunnya nilai $\mathrm{pH}$ tanah menurut kedalaman tidak memperlihatkan suatu pola, namun demikian nilai $\mathrm{pH}$ pada timbunan pertama $(0-50 \mathrm{~cm})$ pada umumnya lebih rendah dibandingkan dua timbunan di bawahnya.
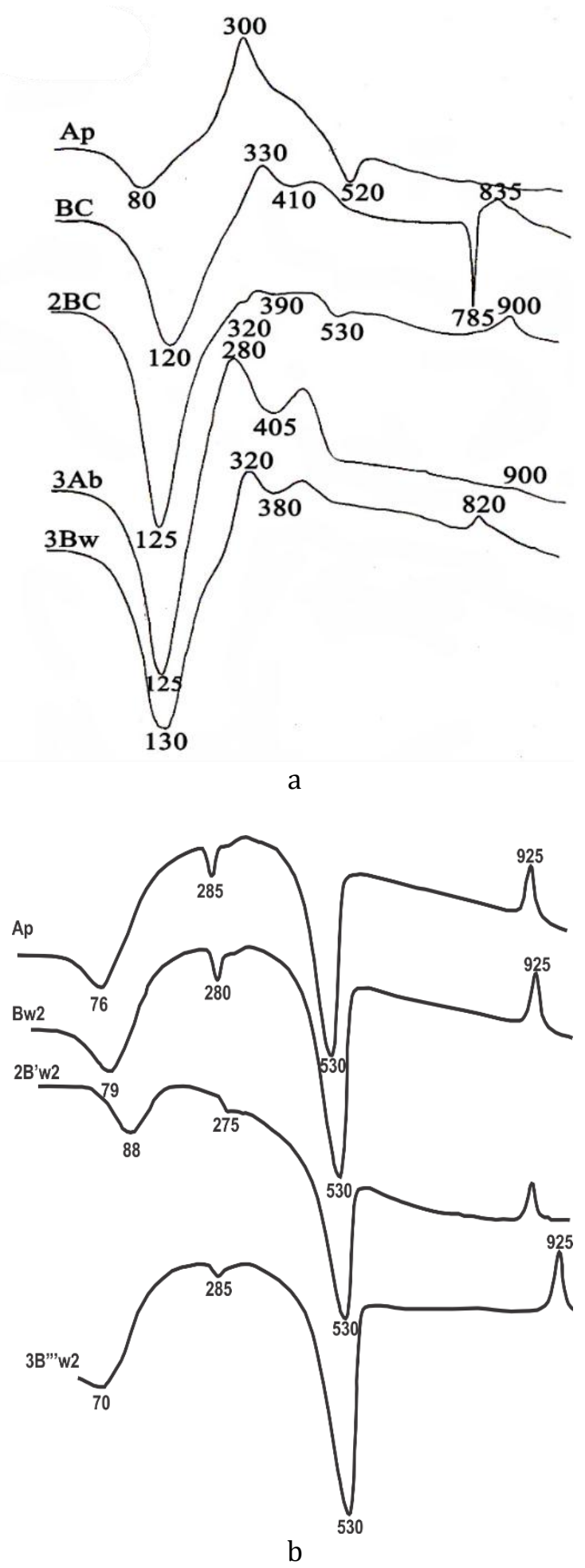

Gambar 3 Kurva Thermogram; Pedon Ciater (a) dan Pedon Jatinangor (b) 
Tabel 3 Komposisi Mineral Liat pada Pedon Ciater dan Pedon Jatinangor

\begin{tabular}{|c|c|c|c|c|}
\hline \multirow{3}{*}{ Pedon } & \multirow{3}{*}{ Horison } & \multicolumn{3}{|c|}{ Puncak Kurva Termogram DTA } \\
\hline & & \multicolumn{2}{|c|}{ Puncak Reaksi } & \multirow{2}{*}{ Jenis Mineral } \\
\hline & & Endotermal $\left({ }^{0} \mathrm{C}\right)$ & Exotermal $\left({ }^{\circ} \mathrm{C}\right)$ & \\
\hline \multirow[t]{5}{*}{ Ciater } & Ap & $80 ; 520$ & 300 & Alofan, imogolit, ferihidrit \\
\hline & $\mathrm{BC}$ & $120: 410 ; 785$ & $330 ; 835$ & Alofan, imogolit, ferihidrit \\
\hline & $2 \mathrm{BC}$ & $125 ; 320 ; 390 ; 530$ & 900 & Alofan, imogolit, ferihidrit \\
\hline & $3 \mathrm{Ab}$ & $125 ; 405$ & $280 ; 900$ & Alofan, imogolit, ferihidrit \\
\hline & $3 \mathrm{Bw}$ & $130 ; 380$ & $320 ; 820$ & Alofan, imogolit, ferihidrit \\
\hline \multirow[t]{4}{*}{ Jatinangor } & Ap & $530 ; 76 ; 285 ; 325$ & 925 & Kaolinit, alofan, gibsit \\
\hline & Bw2 & $530 ; 79 ; 280 ; 320$ & 925 & Kaolinit, alofan, gibsit \\
\hline & 2B'w2 & $530 ; 88 ; 275$ & 925 & Kaolinit, alofan, gibsit \\
\hline & $3 B " ' w 2$ & $530 ; 70 ; 285$ & 925 & Kaolinit, alofan, gibsit \\
\hline
\end{tabular}

Nilai Kapasitas Tukar Kation (KTK) berkisar antara 9,92-49,92 me/100 g, yaitu rendah sampai sangat tinggi. Kation-kation dapat ditukar yang paling dominan hingga yang terendah berturut-turut adalah kalsium, magnesium, natrium dan kalium. Kisaran nilai kalsium adalah 5,62-8,02 me/100 gr (sedang), magnesium 2,35-3,58 me/100 gr (tinggi), natrium $0,36-0,73 \mathrm{me} / 100 \mathrm{gr}$ (sedang), dan kalium 0,06-0,12 me/100 gr (rendah).
Nilai kejenuhan basa (KB) berkisar 20-97 $\%$ yaitu rendah sampai sangat tinggi. Nilai kejenuhan basa yang tinggi perlu perlu dicermat, hal ini bukan berarti tanah tersebut sangat subur mengingat nilai kapasitas tukar kation yang rendah karena mineral fraksi liatnya didominasi oleh kaolinit yang secara alami memiliki muatan netto negatif yang rendah (3-15 me/100 gr liat). Nilai Al-dd berkisar antara 0,00-1,15 me/100 gr.

Tabel 4 Beberapa Sifat Kimia pada Pedon Jatinangor

\begin{tabular}{|c|c|c|c|c|c|c|c|c|c|c|c|c|c|c|}
\hline \multirow{2}{*}{ Horison } & \multirow{2}{*}{ Kedalaman $(\mathrm{cm})$} & \multicolumn{2}{|c|}{$\mathrm{pH}$} & & & \multicolumn{5}{|c|}{ Kation-kation (me/100g) } & \multirow{2}{*}{ KB (\%) } & \multicolumn{2}{|c|}{$\mathrm{me} / 100 \mathrm{~g}$} & \multirow{2}{*}{ EA } \\
\hline & & $\mathrm{H} 2 \mathrm{O}$ & & & & K & $\mathrm{Na}$ & $\mathrm{Ca}$ & $\mathrm{Mg}$ & Jumlah & & $\mathrm{Al}^{3+}$ & $\mathrm{H}^{+}$ & \\
\hline Ap & $0-8$ & 5.45 & 4.38 & 1.23 & 42.92 & 0.19 & 0.43 & 7.05 & 3.58 & 11.25 & 26 & 0.00 & 1.02 & 65.20 \\
\hline Bw1 & $18-34$ & 5.24 & 4.27 & 0.45 & 12.00 & 0.09 & 0.36 & 6.01 & 2.58 & 9.04 & 75 & 1.15 & 0.16 & 61.20 \\
\hline Bw2 & $34-50$ & 5.54 & 4.37 & 0.28 & 10.77 & 0.06 & 0.36 & 6.10 & 2.53 & 9.05 & 93 & 0.93 & 0.39 & 61.50 \\
\hline 2Bwb2 & $90-112$ & 5.63 & 4.63 & 0.21 & 11.26 & 0.11 & 0.58 & 6.64 & 2.59 & 9.92 & 97 & 0.23 & 0.82 & 42.26 \\
\hline 2Bwb3 & $112-138$ & 5.72 & 4.58 & 0.13 & 12.52 & 0.11 & 0.55 & 6.91 & 2.55 & 10.12 & 81 & 0.24 & 0.57 & 32.15 \\
\hline $3 A^{\prime} b$ & $138-154$ & 5.86 & 4.00 & 0.29 & 15.57 & 0.09 & 0.44 & 7.54 & 2.76 & 10.83 & 70 & 0.48 & 0.34 & 43.92 \\
\hline 3B"'wb1 & $154-173$ & 5.49 & 4.63 & 0.21 & 14.06 & 0.09 & 0.55 & 8.00 & 2.83 & 11.47 & 82 & 0.47 & 0.33 & 46.14 \\
\hline 3B"'wb2 & $173-200$ & 5.72 & 4.56 & 0.00 & 12.10 & 0.12 & 0.44 & 8.02 & 3.00 & 11.58 & 82 & 0.24 & 0.85 & 50.89 \\
\hline
\end{tabular}

Tabel 5 Beberapa Sifat Kimia pada Pedon Ciater

\begin{tabular}{|c|c|c|c|c|c|c|c|c|c|c|c|c|c|c|}
\hline \multirow{2}{*}{ Horison } & \multirow{2}{*}{ Kedalaman $(\mathrm{cm})$} & \multicolumn{2}{|c|}{$\mathrm{pH}$} & \multirow{2}{*}{ \% C-Org } & \multirow{2}{*}{ KTK me $/ 100 \mathrm{~g}$} & \multicolumn{5}{|c|}{ Kation-kation (me/100g) } & \multirow{2}{*}{$\mathrm{KB}(\%)$} & \multicolumn{2}{|c|}{$\mathrm{me} / 100 \mathrm{~g}$} & \multirow{2}{*}{$\mathrm{Al}+1 / 2 \mathrm{Fe}$} \\
\hline & & $\mathrm{H} 2 \mathrm{O}$ & $\mathrm{KCl}$ & & & $\mathrm{K}$ & $\mathrm{Na}$ & $\mathrm{Ca}$ & $\mathrm{Mg}$ & Jumlah & & $\mathrm{Al}^{3+}$ & $\mathrm{H}^{+}$ & \\
\hline Ap & $0-17$ & 3.61 & 3.81 & 9.11 & 14.84 & 0.14 & 0.48 & 0.52 & 0.38 & 1.52 & 10 & 3.92 & 0.10 & 3.05 \\
\hline $\mathrm{BC}$ & $31-43$ & 4.14 & 4.45 & 7.52 & 8.45 & 0.22 & 0.53 & 0.25 & 0.04 & 1.04 & 12 & 0.38 & 0.48 & 6.52 \\
\hline $2 \mathrm{Ab}$ & $43-60$ & 4.13 & 4.43 & 5.92 & 12.51 & 0.01 & 0.57 & 0.74 & 0.05 & 1.37 & 11 & 0.26 & 0.46 & 7.17 \\
\hline $3 \mathrm{Ab}$ & $94-110$ & 4.81 & 4.87 & 4.44 & 11.20 & 0.38 & 1.38 & 0.85 & 0.46 & 3.07 & 27 & 0.00 & 0.42 & 10.70 \\
\hline $3 \mathrm{Bw}$ & $110-128$ & 4.73 & 4.87 & 5.55 & 8.50 & 0.26 & 1.07 & 0.31 & 0.11 & 1.75 & 21 & 0.00 & 0.38 & 11.49 \\
\hline 3BC & $128-148$ & 4.51 & 4.87 & 4.04 & 6.16 & 0.17 & 0.45 & 0.39 & 0.02 & 1.03 & 17 & 0.00 & 0.24 & 10.01 \\
\hline
\end{tabular}


Nilai kemasaman terekstrak pada $\mathrm{pH} 8,2$ nilainya berkisar antara 27,28-65,20 me/100 gr, sehingga nilai KTK-jumlah kationnya berkisar antara 76,45-35,85 me/100 gr. Nilai ini menunjukkan bahwa mineral liat tanah Jatinangor memiliki muatan variable (muatan tergantung $\mathrm{pH}$ ) yang cukup tinggi. Muatan ini akan bertambah apabila $\mathrm{pH}$ tanah meningkat, misalnya akibat pengapuran, dan akan menurun apabila $\mathrm{pH}$ tanah turun, misalnya akibat pemupukan yang dapat memasamkan tanah (Urea).

Pengamatan terhadap sifat kimia tanah pada Pedon Ciater menunjukkan nilai $\mathrm{pH}_{2} \mathrm{O}$ sebesar 4,22 dengan kriteria masam. Hal ini terjadi karena pada pedon ini memiliki kandungan C-organik yang tinggi (7,38\%) sehingga berperan dalam meningkatkan kemasaman tanah. Pedon Ciater memiliki curah hujan tinggi dan tanah berkembang dari abu volkan andesit memiliki kandungan total basa yang rendah. Kandungan $\mathrm{Al}$-dd lebih terkait dengan tingkat pelapukan pedon (umur bahan induk), semakin lanjut tingkat pelapukan, umumnya kandungan Al-dd makin meningkat. Kandungan ion H-dd lebih menonjol pada pedon Ciater, kondisi ini dipengaruhi oleh curah hujan yang tinggi di lokasi penelitian. Semakin kering daerahnya maka semakin rendah kandungan $\mathrm{H}-\mathrm{dd}$. Selain itu kandungan $\mathrm{H}$-dd cenderung lebih tinggi pada pedon yang berkembang dari bahan induk tua dibandingkan dari bahan induk yang lebih muda.

\subsection{Sifat Fisika Tanah}

\subsubsection{Tekstur Tanah}

Hasil analisis tekstur tanah menunjukkan bahwa Pedon Jatinangor memiliki kelas tekstur liat atau kelas sebaran butirnya berliat (clayey soil). Fraksi pasirnya relatif sedikit dibandingkan dengan fraksi debunya akibat proses pelapukan yang terus berlanjut. Fraksi pasir dan debu cenderung meningkat seiring meningkatnya kedalaman tanah, sedangkan fraksi liatnya cenderung menurun. Hal ini memperlihatkan terjadi proses pelapukan pada lapisan atas lebih intensif dibandingkan dengan lapisan lebih di bawahnya.

Pada Pedon Ciater, menunjukkan bahwa kandungan debu lebih dominan daripada kandungan liat dan kandungan pasirnya. Fraksi pasirnya lebih sedikit apabila dibandingkan dengan fraksi liatnya dan kandungan debu lebih besar apabila dibandingkan dengan kandungan liatnya. Pedon Ciater ini pada umumnya memiliki kelas tekstur debu pada setiap horisonnya. Hal ini bukan hasil timbunan bahan akibat erosi tetapi merupakan hasil timbunan erupsi volkan. Mengingat lokasi pemilihan pedon berada pada punggung bukit.

\subsubsection{Distribusi Ukuran Partikel}

Pedon Jatinangor fraksi pasirnya didominasi oleh fraksi IV (pasir halus) dan V (pasir sangat halus) (Tabel 6) yang merupakan hasil pelapukan fraksi-fraksi yang lebih kasar. Fraksi debunya didominasi oleh debu berukuran sedang (fraksi VII) dan fraksi liatnya didominasi oleh liat halus (fraksi X). Dominasi fraksi liat halus pada Pedon Jatinangor ini menunjukkan bahwa pelapukan sudah berlangsung cukup lanjut. Bahan-bahan yang asalnya berupa gelas volkanik berukuran debu, pasir, kerakal dan kerikil (lapilli) telah dilapuk menjadi bahan yang sangat halus sehingga tanah memiliki kelas tekstur liat dengan jenis mineral liatnya kaolinit.

Hasil analisis distribusi ukuran partikel Pedon Ciater fraksi pasirnya didominasi oleh fraksi IV (pasir halus) dan V (pasir sangat halus). Fraksi debunya didominasi oleh fraksi debu berukuran sedang (fraksi VII) dan fraksi liatnya didominasi fraksi liat halus (fraksi X). Hasil penilaian kandungan bahan kasar pedon Ciater memiliki bahan kasar 5,81\%, tampaknya kandungan bahan kasar ini tidak dipengaruhi oleh sifat bahan induk dan umur bahan induk tanah tetapi diduga dipengaruhi oleh kekasaran atau kehalusan bahan volkan yang diendapkan. 
Tabel 6 Distribusi Ukuran Pertikel Pedon Jatinangor

\begin{tabular}{|c|c|c|c|c|c|c|c|c|c|c|c|}
\hline \multirow[t]{2}{*}{ Lapisan } & \multirow{2}{*}{$\begin{array}{l}\text { Kedalaman } \\
\quad(\mathrm{cm})\end{array}$} & $\begin{array}{c}\text { fraksi } \\
\text { I }\end{array}$ & $\begin{array}{c}\text { fraksi } \\
\text { II }\end{array}$ & $\begin{array}{c}\text { fraksi } \\
\text { III }\end{array}$ & $\begin{array}{c}\text { fraksi } \\
\text { IV }\end{array}$ & fraksi V & $\begin{array}{c}\text { fraksi } \\
\text { VI }\end{array}$ & $\begin{array}{c}\text { fraksi } \\
\text { VII } \\
\end{array}$ & $\begin{array}{c}\text { fraksi } \\
\text { VIII }\end{array}$ & $\begin{array}{c}\text { fraksi } \\
\text { IX } \\
\end{array}$ & fraksi X \\
\hline & & \multicolumn{5}{|c|}{ Pasir } & \multicolumn{3}{|c|}{ Debu } & \multicolumn{2}{|c|}{ Liat } \\
\hline $\mathrm{Ap}$ & $0-8$ & 0.59 & 0.71 & 1.16 & 2.26 & 2.06 & 2.58 & 12.50 & 0.15 & 8.46 & 69.85 \\
\hline $\mathrm{AB}$ & $8-18$ & 0.30 & 0.37 & 0.58 & 1.25 & 1.14 & 9.73 & 8.18 & 3.58 & 8.58 & 66.09 \\
\hline Bw1 & $18-34$ & 0.39 & 0.20 & 0.62 & 1.35 & 1.25 & 2.54 & 8.86 & 2.27 & 8.85 & 73.87 \\
\hline Bw2 & $34-50$ & 0.52 & 0.72 & 0.66 & 1.49 & 1.66 & 3.20 & 9.20 & 1.70 & 8.23 & 72.62 \\
\hline $2 \mathrm{Ab}$ & $50-68$ & 1.11 & 2.04 & 1.17 & 1.78 & 3.00 & 3.11 & 9.45 & 1.62 & 5.60 & 71.12 \\
\hline $2 B^{\prime} w b$ & $68-90$ & 1.13 & 2.25 & 1.57 & 2.34 & 7.74 & 4.11 & 9.23 & 3.40 & 6.84 & 67.29 \\
\hline 2Bwb2 & $90-112$ & 0.51 & 0.76 & 1.36 & 3.04 & 4.21 & 2.00 & 9.27 & 6.90 & 6.56 & 65.39 \\
\hline 2Bwb3 & $112-138$ & 0.32 & 0.96 & 1.30 & 2.33 & 2.17 & 1.65 & 11.79 & 9.82 & 8.06 & 61.60 \\
\hline $3 A^{\prime} b$ & $138-154$ & 0.01 & 0.74 & 0.99 & 2.07 & 2.45 & 4.43 & 17.34 & 10.05 & 9.49 & 52.43 \\
\hline 3B"'wb1 & $154-173$ & 0.16 & 0.31 & 1.50 & 3.77 & 4.43 & 0.51 & 20.85 & 10.73 & 9.51 & 48.23 \\
\hline 3B"'wb2 & $173-200$ & 0.01 & 0.64 & 0.82 & 2.14 & 2.38 & 3.52 & 23.48 & 9.52 & 7.81 & 49.68 \\
\hline
\end{tabular}

Tabel 7 Distribusi Ukuran Pertikel Pedon Ciater

\begin{tabular}{|c|c|c|c|c|c|c|c|c|c|c|c|}
\hline \multirow[t]{2}{*}{ Lapisan } & \multirow{2}{*}{$\begin{array}{l}\text { Kedalaman } \\
\quad(\mathrm{cm})\end{array}$} & $\begin{array}{c}\text { Fraksi } \\
\text { I }\end{array}$ & $\begin{array}{c}\text { fraksi } \\
\text { II }\end{array}$ & $\begin{array}{c}\text { fraksi } \\
\text { III }\end{array}$ & $\begin{array}{c}\text { fraksi } \\
\text { IV }\end{array}$ & $\begin{array}{c}\text { fraksi } \\
\mathrm{V}\end{array}$ & $\begin{array}{c}\text { fraksi } \\
\text { VI }\end{array}$ & $\begin{array}{c}\text { fraksi } \\
\text { VII }\end{array}$ & $\begin{array}{c}\text { fraksi } \\
\text { VIII }\end{array}$ & $\begin{array}{c}\text { fraksi } \\
\text { IX }\end{array}$ & $\begin{array}{c}\text { fraksi } \\
\text { X }\end{array}$ \\
\hline & & & & Pasir & & & & Debu & & \multicolumn{2}{|c|}{ Liat } \\
\hline Ap & $0-17$ & 3.03 & 3.36 & 8.99 & 17.69 & 15.28 & 11.82 & 18.54 & 11.32 & 8.96 & 0.74 \\
\hline Bw & $17-31$ & 1.18 & 2.32 & 4.91 & 8.88 & 11.56 & 8.78 & 35.49 & 0.53 & 1.16 & 28.19 \\
\hline $\mathrm{BC}$ & $31-43$ & 4.59 & 10.23 & 12.29 & 9.08 & 5.85 & 2.82 & 13.29 & 3.90 & 0.08 & 37.87 \\
\hline $2 \mathrm{Ab}$ & $43-60$ & 2.46 & 2.12 & 4.44 & 8.20 & 8.08 & 8.29 & 31.19 & 5.59 & 13.88 & 15.75 \\
\hline $2 \mathrm{Bw}$ & $60-70$ & 0.47 & 1.90 & 5.34 & 7.45 & 7.45 & 3.54 & 40.82 & 12.05 & 2.41 & 18.57 \\
\hline $2 \mathrm{BC}$ & $70-94$ & 2.45 & 4.41 & 9.15 & 11.81 & 6.94 & 5.87 & 21.00 & 7.53 & 1.41 & 29.43 \\
\hline $3 \mathrm{Ab}$ & $94-110$ & 0.29 & 0.43 & 2.39 & 4.35 & 3.84 & 6.75 & 19.72 & 4.64 & 23.52 & 18.89 \\
\hline 3Bw & $110-128$ & 0.33 & 0.38 & 2.84 & 5.29 & 2.28 & 6.20 & 16.78 & 9.46 & 6.10 & 50.34 \\
\hline $3 \mathrm{BC}$ & $128-148$ & 0.49 & 0.80 & 5.93 & 7.40 & 3.69 & 6.44 & 19.65 & 11.75 & 43.85 & 0.00 \\
\hline
\end{tabular}

Perbedaan tingkat pelapukan antara bahan erupsi pertama dengan bahan hasil erupsi kedua tampak jelas dari susunan fraksi debu berukuran sedang, sedangkan perbedaan bahan antara timbunan bahan hasil erupsi kedua dengan hasil erupsi pertama terlihat pada susunan fraksi pasirnya, terutama fraksi I dan II.

\subsection{Proses Pembentukan Tanah}

Proses perkembangan tanah pada Pedon Jatinangor baru mencapai tahap viril atau tahap kambik yaitu terbentuknya horison bawah B-kambik (Bw). Horison kambik ini merupakan horison alterasi bahan induk volkanik dimana penimbunan bahan dari hasi pencucian horison di atasnya belum signifikan untuk suatu horison argilik atau kandik. Warna horison kambik lebih terang (coklat) dibandingkan dengan horison di atasnya. Adanya penimbunan bahan volkan yang berulang-ulang dari erupsi yang berbeda umurnya mengakibatkan proses pembentukan tanah terhambat sehingga tanah senantiasa berumur dewasa. Apabila ditinjau dari komposisi mineral liatnya Pedon Jatinangor didominasi oleh mineral kaolinit, yang merupakan suatu bukti bahwa pelapukan pada pedon ini telah berlangsung lanjut. Perubahan mineral pada Pedon Jatinangor menjadi kaolinit dan gibsit memerlukan waktu yang cukup lama (beberapa abad), sehingga perkiraan bahan hasil erupsi berumur awal kuarter (pleistosen) cukup rasional.

Proses pembentukan tanah yang utama pada pedon Ciater adalah pelapukan mineralmineral ordo kisaran pendek seperti alofan, imogolit dan ferihidrit, melalui pencucian unsur-unsur mudah larut dan kopresipitasi gel-gel $\mathrm{SiO}_{2}$ dan $\mathrm{Al}_{2} \mathrm{O}_{3}$. Resilikasi mineralmineral ordo kisaran pendek menghasilkan mineral liat haloisit sedangkan desilikasi menghasilkan mineral liat gibsit. Tingkat perkembangan tanah pada Pedon Ciater ini termasuk tahap viril atau cambic. 


\subsection{Klasifikasi Tanah}

Hasil penelusuran sistem kunci pada Taksonomi Tanah (Soil Survey Staff, 2014) dengan mencocokan data-data morfologi, fisika, kimia dan mineralogi yang diperoleh dari hasil analisis laboratorium dan lapangan dengan faktor-faktor pembeda pada setiap kategori Taksonomi Tanah, maka Pedon Jatinangor dapat diklasifikasikan sebagai Fluventic Eutrudepts, berliat, kaolinitik, isohipertermik. Tanah ini memiliki kandungan bahan organik 0,2 persen atau lebih pada kedalaman $125 \mathrm{~cm}$ di bawah permukaan tanah, kejenuhan basa tinggi $>60 \%$ pada satu horison atau lebih diantara kedalaman 25 - 75 $\mathrm{cm}$, memiliki kandungan liat 35 persen atau lebih, didominasi oleh mineral liat kaolinit dan suhu tanah tahunan rata-rata $22^{\circ} \mathrm{C}$.

Klasifikasi tanah pada kategori famili Pedon Ciater yaitu tanah Andisol yang berkembang dari bahan induk abu volkan andesitik adalah Acrudoxic Durudands, medial di atas skeletal berlempung, amorphik, isohiperthermic. Tanah ini memiliki horison tersementasi $75 \%$ atau lebih yang batas atasnya di dalam $100 \mathrm{~cm}$ dari permukaan tanah mineral, memiliki jumlah basa-basa terekstrak dan $\mathrm{Al}^{3+}$ terekstrak dengan $\mathrm{KCl} 1 \mathrm{~N}$ sebesar kurang dari 2,0 cmol/kg dalam fraksi tanah halus dengan ketebalan total $30 \mathrm{~cm}$ diantara kedalaman $25 \mathrm{~cm}$ dan horison tersementasi.

\section{KESIMPULAN}

Pedon Jatinangor berkembang dari bahan volkan andesitik yang berumur awal kuarter (plestosen) dan Pedon Ciater berkembang dari bahan volkan andesitik yang berumur holosen akhir masing-masing terdiri dari tiga stratifikasi bahan yang berbeda umurnya menunjukkan adanya ketidaksinambungan litologik (lithologic Discontinuity).

Pedon Jatinangor memiliki komposisi mineralogi liat didominasi oleh kaolinit dengan asosiasi mineral fraksi pasir/fraksi berat augit-hiperstin, sedangkan Pedon Ciater memiliki komposisi mineralogi liat didominasi oleh alofan dan asosiasi mineral fraksi pasir/fraksi berat adalah amfibol hijauhiperstin di timbunan pertama dan augitamfibol pada timbunan di bawahnya.

Tingkat perkembangan tanah pada kedua pedon telah berlangsung pada tahap viril atau kambik, dimana terjadi alterasi bahan induk dan pembentukan warna yang lebih merah di horison bawahnya.

Klasifikasi tanah menurut Taksonomi Tanah ((Soil Survey Staff, 1999; 2014) pada kategori famili, Pedon Ciater yaitu Acrudoxic Durudands, medial diatas skeletal berlempung, amorfik, isohipertermik, sedangkan Pedon Jatinangor yaitu Fluventic Eutrudepts, halus, kaolinitik, isohipertermik.

\section{DAFTAR PUSTAKA}

Dudal, R. and M. Soepraptohardjo. 1961. Some Consideration on the Genetic Relationship between Latosols and Andosols in Java (Indonesia). Trans. Of $7^{\text {th }}$ Int. Cong. Of Soil Science. IV. Madison, Wisconsin, USA.

Rachim, D. A. 2007. Dasar-dasar Genesis Tanah. Departemen Ilmu Tanah dan Sumberdaya Lahan Faperta IPB. Bogor. 364p.

Rachim, D. A. Dan M. Arifin. 2011. Dasar-dasar Klasifikasi Taksonomi Tanah. Cetakan Pertama. Pustaka Reka Cipta, Bandung.

Soil Survey Staff. 1998. Kunci Taksonomi Tanah. Edisi Kedua Bahasa Indonesia. 1999. Pusat Penelitian Tanah dan Agroklimat. Badan Penelitian dan Pengembangan Pertanian.

Soil Survey Staff. 2014. Key to Soil Taxonomy. Twelfth Edition. United States Department of Agriculture Natural Resources Conservation Service. USA. 